\title{
HOMLOKMART FELÜLET ÉRDESSÉGE AZ ELÖTOLÁS ÉS A FORGÁCSARÁNY VÁLTOZTATÁSÁNAK HATÁSÁRA ROMBUSZ ALAKÚ LAPKA ALKALMAZÁSÁVAL
}

\author{
Nagy Antal \\ mérnöktanár, Miskolci Egyetem, Gyártástudományi Intézet \\ 3515 Miskolc, Miskolc-Egyetemváros, e-mail: antal.nagy@uni-miskolc.hu
}

\begin{abstract}
Absztrakt
A felületi érdesség hatással van az alkatrészek illeszkedésére, élettartamára és a szerkezeti egységek müködési követelményeinek megfelelésére, emiatt kell terveznünk annak várható értékét. A homlokmarásra jellemzö kinematika révén a felület érdessége inhomogén lesz, vagyis a felületet különböző irányokban mérve változó értékeket mutat. A cikkben az előtolás növelésének hatását vizsgáltuk a felületi érdességre, mivel az elötolás növelése a termelékenység fokozásának egy hatékony módja.
\end{abstract}

Kulcsszavak: homlokmarás, felületi érdesség, elötolás, forgácsarány

\section{Abstract}

Surface roughness affect the fit, the lifetime and the performance requirements of parts and structural units. Thus, we must plan the expected value of that. Due to the characteristic kinematics of face milling, the roughness of the surface is inhomogeneous, which means different roughness in different directions measured on the surface. We examined the effect of the change of feed rate on the surface roughness in this article since increasing feed rate is an effective way to increase productivity.

Keywords: face milling, surface roughness, feed rate, chip size ratio

\section{Bevezetés}

Minden alkatrész befejező megmunkálásának célja az alkatrészrajzon elöírt érdességi és pontossági követelmények teljesítése. A müködési követelményeknek megfelelő érdességi értékek elérésére széleskörü kutatások folynak, többek között a homlokmarásra is. Erre utal a vizsgált témával kapcsolatos közlemények viszonylag nagy száma is. Mansour et al. [1] a forgácsolási adatok hatását, míg Zhao et al. [2] azt vizsgálta, hogy a beállított technológiai adatok változtatása milyen mértékben módosítja az érdességet. Baek et al. [3] figyelembe vette a lapkák ütését is egy matematikai modell továbbfejlesztéséhez, amit minden esetben előre be kell mérni. Kundrák és Felhő [4] vizsgálta különböző $\mathrm{a}_{\mathrm{p}} / \mathrm{f}_{\mathrm{z}}$ arányok mellett a két- és háromdimenziós felületi érdességi mérőszámok változását öt lapkára, az ütések figyelembevételével. Megállapították, hogy az előtolás függvényében - a vizsgált beállításoknál a felületnek 1,44...7,71-szer rosszabb az érdessége, mint a bázisnak választott ütésmentes szerszámmal megmunkált felületé [5]. A forgácsolt felületek érdességének előzetes becslése is fontos kutatási irány [6,7], mert lehetőséget biztosít a megmunkált felület érdességének tervezéséhez.

E rövid irodalmi áttekintésben is látható, hogy a különböző forgácsolási feltételek (munkadarabszerszám anyag párosítás és technológiai paraméterek) mellett végzett megmunkáláskor nem teljesen 
azonos a felületi érdességet befolyásoló tényezők megítélése és hatásuk intenzitása az érdességi paraméterek értékére. Jelen cikkben szimmetrikus marásnál vizsgálom az előtolás növelésének hatását a felületi érdesség változására. Mivel a fogásmélység és az előtolás jelentős változtatásának hatására megváltozik a forgácsdeformáció is, ezért elemzem $a z a_{\mathrm{p}} / \mathrm{f}_{\mathrm{z}}$ forgácsarány változását is a felületi érdességre. E cikkben bemutatott kutatásaim során figyelembe vettem olyan forgácsolási adatpárokat is, amelyeket nagy előtolásoknál az utóbbi időben javasolnak a kutatók. Ilyen nagy előtolású homlokmarással kialakuló felületek 2D és 3D érdességi jellemzöit vizsgálta Karpuschewski et al. [8].

\section{Kísérleti körülmények}

A kísérleteket a Miskolci Egyetem Gyártástudományi Intézetében lévő Perfect Jet MCV-M8 függőleges marógépen végeztem. A homlokmaró fejen (névleges átmérő: $\mathrm{D}_{\mathrm{t}}=80 \mathrm{~mm}$ ) csak egy fészekbe szereltem R215.44-15T308M-WL rombusz alakú, bevonatolt keményfém lapkát. A szerszám fóél-elhelyezési szöge $\kappa_{\mathrm{r}}=90^{\circ}$, homlokszöge $\gamma_{\mathrm{o}}=0^{\circ}$, hátszöge $\alpha_{0}=11^{\circ}$, a csúcssugár pedig $\mathrm{r}_{\varepsilon}=0,8 \mathrm{~mm}$.

A kísérletek normalizált állapotú C45 minőségü ötvözetlen acél (1.0503) munkadarabokon lettek elvégezve szimmetrikus beállítással. Az ilyen anyagminőségre jellemző szakítószilárdság $580 \mathrm{MPa}$ és keménység $207 \mathrm{HBW}$ [9]. A forgácsolt felület szélessége $58 \mathrm{~mm}$, hossza $50 \mathrm{~mm}$. A kísérletek forgácsolási adatait, úgy az $\mathrm{a}_{\mathrm{p}}$ fogásmélységet, az $\mathrm{f}_{\mathrm{z}}$ fogankénti elötolást, az előzők hatványaként alkotott $\mathrm{a}_{\mathrm{p}} / \mathrm{f}_{\mathrm{z}}$ forgácsviszonyt és a $\mathrm{v}_{\mathrm{c}}$ forgácsoló sebességet az 1 . táblázat tartalmazza.

1. táblázat. Alkalmazott forgácsolási adatok és a mérési helyek

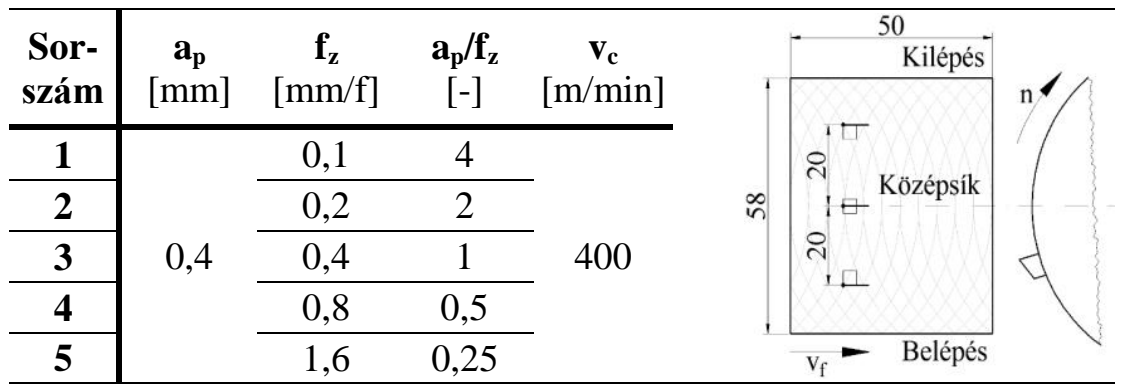

Az érdességméréseket AltiSurf 520 3D érdességmérő gépen végeztem el, a szimmetriasíkban, és két azzal párhuzamos mérési síkban (1. táblázat). Az eredményeket AltiMap szoftverben értékeltem ki. A vonalmenti mérések érdességi méröszámait az ISO 4288:1998 szabvány előírásait követve kaptam meg. A 3D mérések a mérési síkokhoz igazítva lettek felvéve szimmetrikusan, a területei egyenként $2,5 \times 2,5$ mm-esek.

2. táblázat. Felületi érdességi értékek

\begin{tabular}{|c|c|c|c|c|c|c|c|c|c|c|c|c|}
\hline & \multicolumn{3}{|c|}{$\mathbf{R}_{\mathrm{a}}[\boldsymbol{\mu} \mathrm{m}]$} & \multicolumn{3}{|c|}{$\mathbf{R}_{\mathrm{z}}[\boldsymbol{\mu} \mathbf{m}]$} & \multicolumn{3}{|c|}{$\mathbf{S}_{\mathrm{a}}[\boldsymbol{\mu m}]$} & \multicolumn{3}{|c|}{$S_{z}[\mu \mathrm{m}]$} \\
\hline & Be & Köz & $\mathbf{K i}$ & Be & Köz & $\mathbf{K i}$ & Be & Köz & $\mathbf{K i}$ & Be & Köz & $\mathbf{K i}$ \\
\hline I & 0,33 & & & 1,93 & 1,51 & 1,82 & 0,40 & & 0,39 & 2,52 & 2,51 & 2,60 \\
\hline & & & & & & & & & & & & \\
\hline & & & 1,2 & 6,49 & 10 & & 2,41 & & & 11,97 & 12 & 11,99 \\
\hline 6 & 6,44 & 7,84 & 4,03 & 23,86 & 29,31 & 16,74 & 5,29 & 7,6 & 4,79 & 25,90 & 33 & 26,10 \\
\hline 8 & 16,49 & 19,16 & 9,12 & 49,91 & 65,85 & 38,64 & 11,16 & 15,52 & 12,37 & 59,20 & 66,48 & 66,35 \\
\hline
\end{tabular}




\section{Mérési eredmények}

Az ismert érdességi paraméterek közül csak az $R_{a}$ illetve $a z R_{z}$ értékeket, illetve ezek 3D-s megfelelöit $\left(S_{a}\right.$ és $\left.S_{z}\right)$ közlöm a 2. táblázatban. A felületekröl készült érdességi profilgörbéket az 1. ábra tartalmazza a mérési síkok és az előtolás szerint rendszerezve. Itt csak az $\mathrm{f}_{\mathrm{z}}=0,1 ; 0,4$ és 1,6 $\mathrm{mm} /$ fordulat előtolásokhoz tartozókat tüntetem fel. Ezenfelül a mérések során a vizsgált felületek topográfiáit is rögzítettem, itt csak a 3. beállításról készült felvételeket mutatom meg (1. ábra).

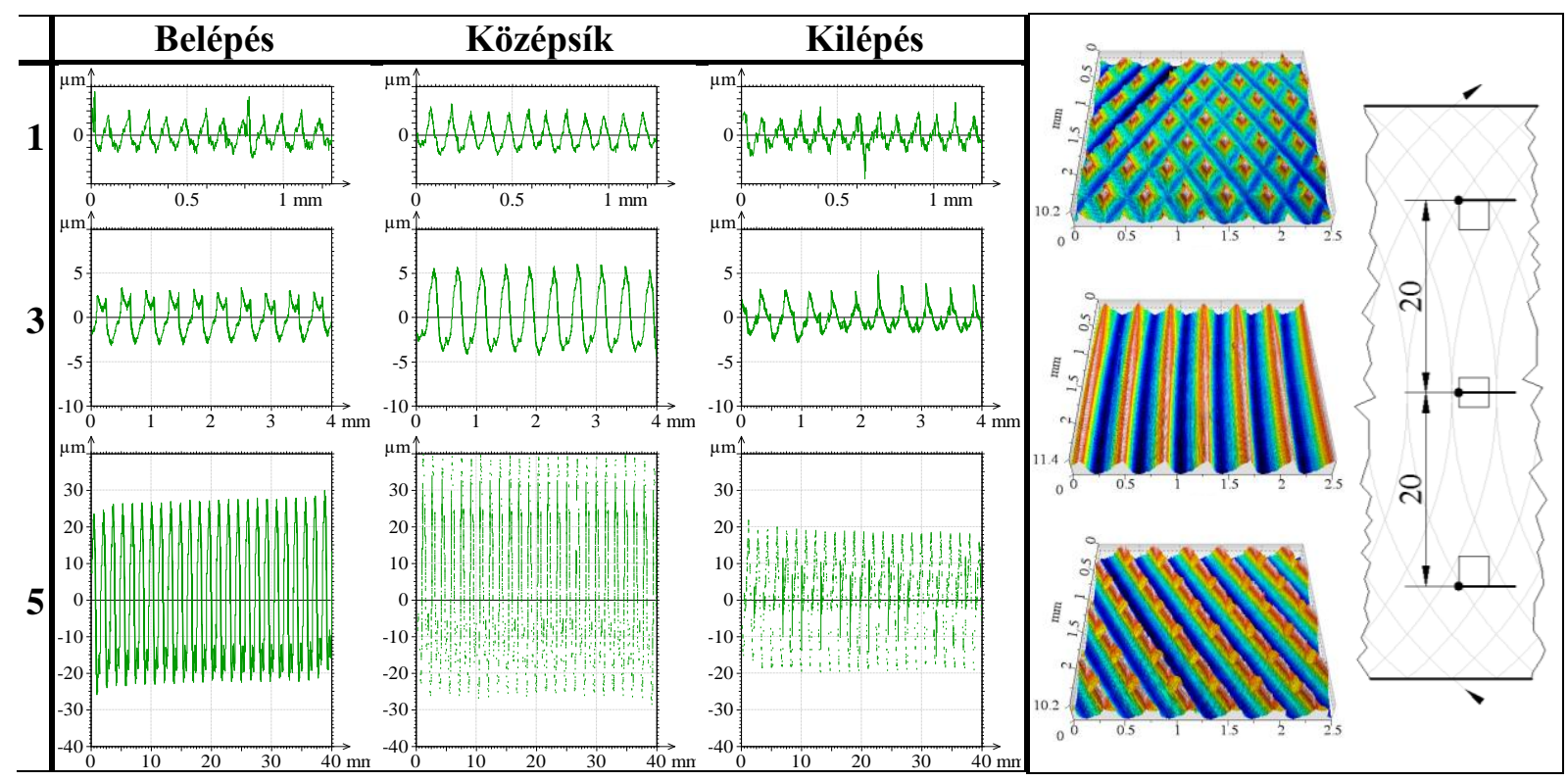

1. ábra. Érdességi profilgörbék és felületi topográfiák a mart felületekröl $\left(a_{p}=0,4 \mathrm{~mm} ; v_{c}=400 \mathrm{~m} / \mathrm{min}\right.$, $f_{z}=0,1 \mathrm{~mm} /$ ford. (1); $f_{z}=0,4 \mathrm{~mm} / \mathrm{ford} .(3) ; f_{z}=1,6 \mathrm{~mm} /$ ford. (5) )

\section{Eredmények kiértékelése}

Az 1. ábrán a felvételeken jól észrevehetők a jellegzetes érdességi lenyomatok. A középsíkban csak a mart felület érdességi profilja látszik, a szélső oldalakon a fő és visszafutó él lenyomatai is megjelennek. A kilépő oldalon sokkal mélyebb barázdák láthatók, ezt a 2. táblázatban közölt értékek is jól mutatják, amelyek nagyobbak a belépő oldalnál. A számszerü 2D és 3D mérési eredményeket diagramokban ábrázolom a fogankénti elötolás $\mathrm{f}_{\mathrm{z}}$ és a forgácsarány $\mathrm{a}_{\mathrm{p}} / \mathrm{f}_{\mathrm{z}}$ szerint rendezve, amely szemléletessé teszi azok alakulásait, illetve elősegíti a kiértékelésüket is (2. ábra). A diagramok azt mutatják, hogy az előtolás növelésével közel lineárisan növekednek az érdességi értékek. $\mathrm{Az} \mathrm{f}_{\mathrm{z}} \leq 0,4$ $\mathrm{mm} /$ ford. esetén a síkok értékei közt alig van eltérés, illetve a 2. táblázatban látható, hogy a szimmetriasíkban mért értékek a legkisebbek. Az előtolást növelve éppen megfordul ez a viszony; a különbségek egyre nagyobbak, és a középsíkban vannak a maximális értékek. Továbbá elméletileg a középsíkhoz képest azonos távolságban lévő síkokban azonosak az érdesség értéke [10]. Ez a kísérletek során nem igazolódott, a belépő oldalon nagyobb értékek adódtak. Ennek oka a belépö oldalon a középsíkig tartó ellenirányú és utána egyenirányú marás váltakozása. Így a feltételezés, hogy a maximális érdességhez elegendő a középsíkban mérni, nem minden esetben igazolható. 


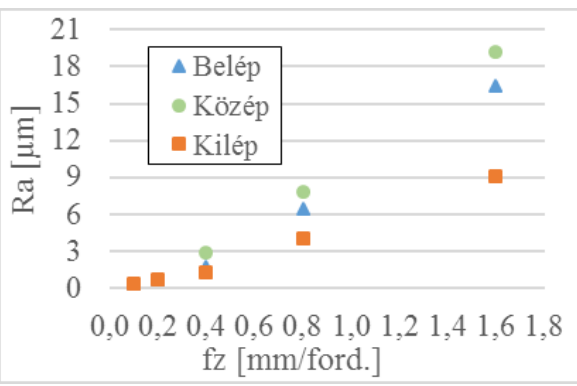

a)

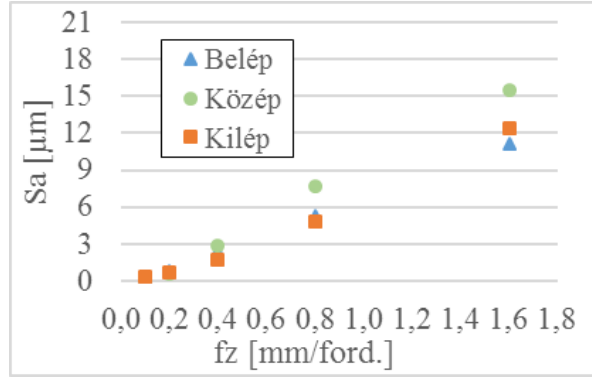

c)

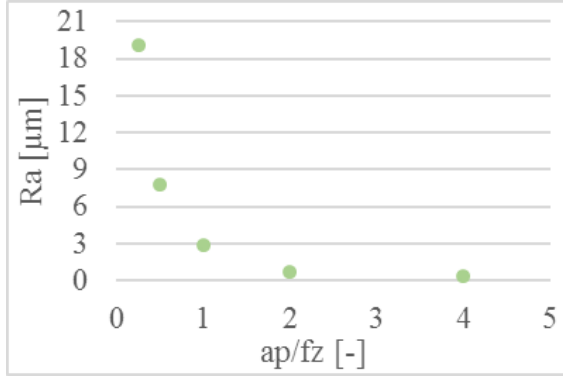

e)

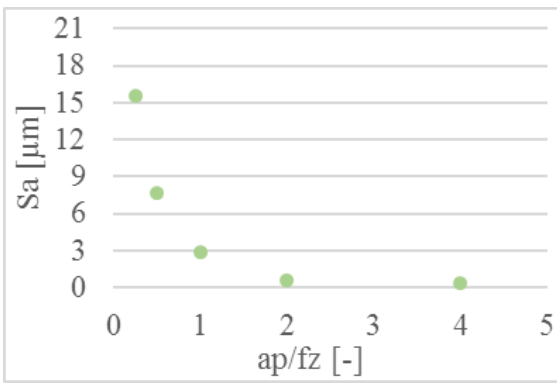

g)

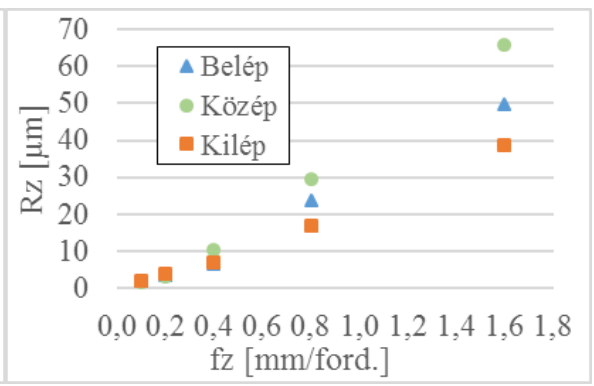

b)

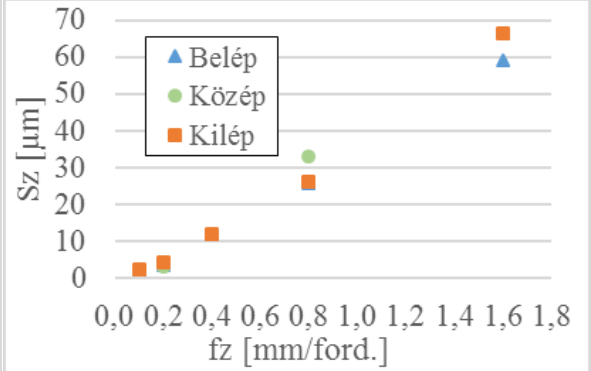

d)

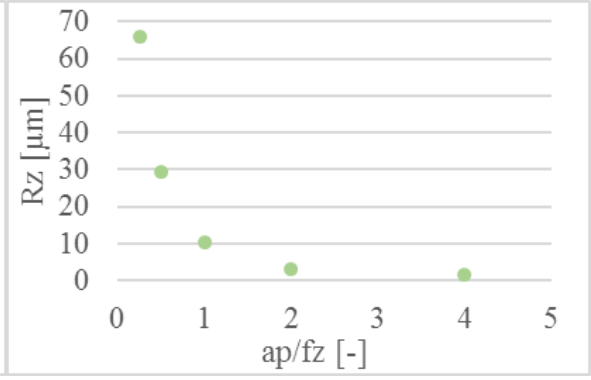

f)

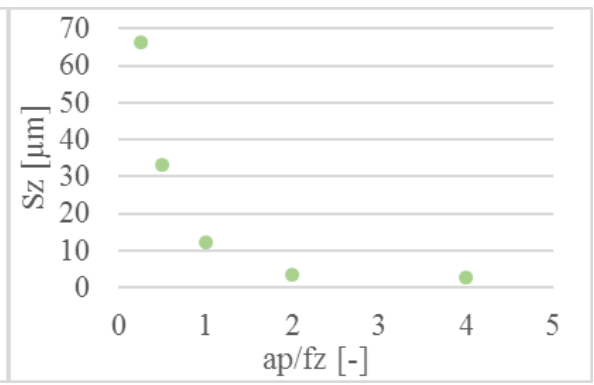

h)

2. ábra. Mérési eredmények az elötolás $f_{z}$ és a forgácsarány $a_{p} / f_{z}$ függvényében

A 2. ábra e-h) diagramjain a középsík érdességi értékei láthatók. Ezeket figyelve elmondható, hogy $a_{\mathrm{p}} / \mathrm{f}_{\mathrm{z}}>1$ esetén az $\mathrm{R}_{\mathrm{a}}$ és $\mathrm{S}_{\mathrm{a}}$ átlagos érdességek $3 \mu \mathrm{m}$, az $R_{\mathrm{z}}$ és $S_{\mathrm{z}}$ egyenetlenség magasságok pedig 12,5 
$\mu \mathrm{m}$ alatt maradnak. Ellenkező esetben, például nagyobb előtolást választva az értékek ugrásszerüen növekednek. A 3D értékek alakulása megegyezik a 2D esetével.

\section{5. Összefoglalás}

A vizsgálat arra irányult, hogyan változott az érdesség ötvözetlen acél szimmetrikus homlokmarásánál, egyetlen szerelt lapkával, az előtolás hatására. Az elkészített próbadarabok felületi érdességét három párhuzamos síkban mértem.

Megállítható, hogy $\mathrm{a}_{\mathrm{p}} / \mathrm{f}_{\mathrm{z}}>1$ megválasztásakor az érdességi értékek kicsik, és változásuk nagyon csekély, egyéb esetben azok jelentősen növekedtek. Így 1-nél nagyobb értékek javasolhatók. A maximális érdességet a mart felület különbözö pontjaiban mértem, ez alapján javaslom a mart felületet lefedő, párhuzamos síkokban is az érdességmérést. A párhuzamos síkokban - elméletileg azonos értékektől [10] eltérően - azok különbséget mutatnak. A belépő oldalon, ahol ellenirányú a marás, nagyobbak lesznek az érdességi értékek.

\section{Köszönetnyilvánítás}

A cikkben ismertetett kutató munka az EFOP-3.6.1-16-2016-00011 jelű „Fiatalodó és Megújuló Egyetem - Innovatív Tudásváros - a Miskolci Egyetem intelligens szakosodást szolgáló intézményi fejlesztése" projekt részeként - a Széchenyi 2020 keretében - az Európai Unió támogatásával, az Európai Szociális Alap társfinanszírozásával valósul meg.

\section{Irodalom}

[1] Mansour, A., Abdalla, H.: Surface roughness model for end milling: a semi-free cutting carbon casehardening steel (EN32) in dry condition, Journal of Materials Processing Technology 2002, 124:183-191. https://doi.org/10.1016/S0924-0136(02)00135-8

[2] Zhao, G., Guo, Y. B., Zhu, P., Zhao, Y.: Energy Consumption Characteristics and Influence on Surface Quality in Milling, Procedia CIRP 2018, 71:111-115. https://doi.org/10.1016/j.procir.2018.05.081

[3] Baek, D. K., Ko, T. J., Kim, H. S.: Optimization of feedrate in a face milling operation using a surface roughness model, International Journal of Machine Tools \& Manufacture 2001, 41:451462. https://doi.org/10.1016/S0890-6955(00)00039-0

[4] Kundrák, J., Felhő, C.: Investigation of the topography of face milled surfaces, Materials Science Forum 2018, 919:78-83. https://doi.org/10.4028/www.scientific.net/MSF.919.78

[5] Felhö, C., Kundrák, J.: Effects of Setting Errors (Insert Run-Outs) on Surface Roughness in Face Milling When Using Circular Inserts, Machines 2018, 6(2):14. https://doi.org/10.3390/machines6020014

[6] Kundrák, J., Felhő, C.: 3D roughness parameters of surfaces face milled by special tools, Manufacturing Technology 2016, 16(3):532-538.

[7] Felhő, C., Kundrák, J.: Comparison of theoretical and real surface roughness in face milling with octagonal and circular inserts, Key Engineering Materials 2014, 581:360-365. https://doi.org/10.4028/www.scientific.net/KEM.581.360

[8] Karpuschewski, B., Kundrák, J., Emmer, T., Borysenko, D.: A new strategy in face milling inverse cutting technology, Solid State Phenomena 2017, 261:331-338. https://doi.org/10.4028/www.scientific.net/SSP.261.331 
[9] European Steel and Alloy Grades, C45

http://www.steelnumber.com/en/steel_composition_eu.php?name_id=152

[10] Felhő, C., Karpuschewski, B., Kundrák, J.: Surface roughness modelling in face milling, Procedia CIRP 2015, 31:136-141. https://doi.org/10.1016/j.procir.2015.03.075 